\title{
Efficacy of Liquid Protein Hydrolysate from Chicken Feather by Pseudomonas sp. on the Growth of Cucumis sativus ${ }^{\dagger}$
}

\author{
Petchi Iyappan ${ }^{1}$, Elvin Nickson Lewis ${ }^{1}$, Shatiswaran Raghu ${ }^{1, *}$ \\ 1 School of Bioscience, Faculty of Medicine, Bioscience and Nursing, MAHSA University Bandar Saujana Putra, 41200, \\ Selangor, Malaysia \\ * Correspondence: shatishpanda@gmail.com; \\ $\uparrow$ Presented at International e-Conference on Bioengineering for Health and Environment (ICBHE 2020)
}

Received: 5.07.2020; Revised: 10.07.2020; Accepted: 12.07.2020; Published: 15.07.2020

\begin{abstract}
Keratin, which made up the chicken feather, is difficult to be broken down by the proteolytic enzyme. Annually, millions of tons of chicken feathers are disposed of worldwide as waste without realizing the high protein content in the feather. Due to the presence of keratinase from keratinolytic bacteria, chicken feathers are disposed of together with poultry excreta. Therefore, this study is conducted to study the ability of liquid protein hydrolysate produced by bacteria in poultry excreta to utilize into biofertilizing and biocontrol. Keratinolytic bacteria are identified from poultry excreta by screening. The isolated enzyme was optimized in various conditions such as different $\mathrm{pH}$, temperature, and feather concentration as well as nitrogen and carbon sources. Enzymatic activity increased gradually from $1 \%$ to $5 \%$ in carbon and nitrogen sources. Liquid protein hydrolysate was used to study the biofertilizing ability on the growth of Cucumis sativus and antibacterial effect on Escherichia coli. Pseudomonas $s p$. has the capability to degrade the feather on $10^{\text {th }}$ day due to the high enzymatic activity. Pseudomonas sp. shows high enzymatic activity at $37^{\circ} \mathrm{C}, \mathrm{pH} 8$, and feather concentration at $0.5 \%$. The chlorophyll estimation shows a p-value $<0.05$ after being treated with liquid protein hydrolysate. Liquid protein hydrolysate promoted the growth of Cucumis sativus as well as Pseudomonas sp. The antibacterial properties can also be seen against Escherichia coli. In a nutshell, chicken feather produces liquid protein hydrolysate, which has biofertilizing properties. The full potential of liquid hydrolysate can be understood with further analysis of peptide in protein hydrolysate.
\end{abstract}

Keywords: Keratin; chicken feather; Keratinolytic bacteria; biofertilizer.

(C) 2020 by the authors. This article is an open-access article distributed under the terms and conditions of the Creative Commons Attribution (CC BY) license (https://creativecommons.org/licenses/by/4.0/).

\section{Funding}

This research received no external funding.

\section{Acknowledgments}

This research has no acknowledgment.

\section{Conflicts of Interest}

The authors declare no conflict of interest. 